\title{
The Phytoplankton and Water Quality of Sennar and Roseires Reservoirs, Sudan
}

\author{
By Faisal Abdalla Sinada ${ }^{*} \&$ Manal Elsayed Abdelrahman ${ }^{\dagger}$
}

The aim of the study was to evaluate the effect of heightening of Roseires Dam on the phytoplankton and physico-chemical characteristics of Sennar reservoir $\left(13^{\circ} 32^{\prime} 55^{\prime \prime}\right.$ and

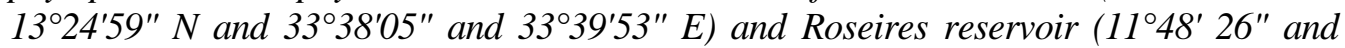
$11^{\circ} 32^{\prime} 45^{\prime \prime} N$ and $34^{\circ} 26^{\prime} 46^{\prime \prime}$ and $34^{\circ} 28^{\prime} 33^{\prime \prime} E$ ) on the Blue Nile, Sudan. The heightening project that was completed in 2013 increased the storage capacity of Roseires reservoir from $3.0 \times 10^{9} \mathrm{~m}^{3}$ to $7.4 \times 10^{9} \mathrm{~m}^{3}$. The study provides baseline data before the completion of the Grand Ethiopian Renaissance Dam (GERD) on the Blue Nile. No studies on the phytoplankton of Sennar or Roseires reservoir have been undertaken since late 1960s because of accumulating deficit of trained research personnel and the very low level of scientific research funding. Present water analyses include Secchi transparency, electrical conductivity, $\mathrm{pH}$, alkalinity, nitrate-nitrogen, phosphate-phosphorus, calcium, potassium, sodium, cadmium, cobalt, chromium, copper, iron, lead, magnesium, manganese, and zinc. Statistical analysis shows that there were no significant differences between the samples taken from Sennar and Roseires reservoirs. The quality of the water of the two reservoirs has not changed since 1960s, still being within allowable limits set by the Sudanese Standards and Metrology Organization and WHO for drinking. Strikingly, algal biomass remained extremely low in the two reservoirs during the present study. Visual observations and analysis of water samples collected from the two reservoirs and from the Blue Nile at Khartoum showed that the recurrent peaks reported by previous workers did not appear, while turbidity and concentrations of nutrients remained unexpectedly high with no signs of any algal growth during December 2015 - December 2017. Environmentalists are alarmed that pollution in the Blue Nile within Sudan will become a problem after the completion of GERD when regulation of water flow downstream will result in only a fraction of the Blue Nile water reaches Sudan throughout the year allowing for the accumulation of pollutants.

Keywords: Blue Nile, Phytoplankton, Roseires Dam, Sennar Dam, Water Quality.

\section{Introduction}

Published work on assessment of possible contamination or development of any degree of pollution of the Blue Nile is non-existent. In view of the social progress, industrial and population explosion and active urbanization that took place within the last fifty years and which shall continue in the coming years, pollution of the Blue Nile is inevitable unless certain measures are undertaken.

Attention is focused on the detection of unwelcome enrichments which cause deterioration of water quality. These undesirable contaminants might reach the course of the river as a result of (i) introduction of industrial contaminants from the many factories built along the Blue Nile, (ii) sewage effluent and urban runoff

\footnotetext{
*Associate Professor, University of Khartoum, Sudan.

${ }^{\dagger}$ Assistant Professor, University of Khartoum, Sudan.
} 
from expanding towns adjacent to the Blue Nile and/or (iii) diffusion of agrochemicals from Sudan Gezira agriculture scheme and other farms.

The Blue Nile after leaving Lake Tana, quickly descends into a deep gorge until it enters the Sudan south of Roseires with average annual flow of $46.2 \times 10^{9}$ $\mathrm{m}^{3} \mathrm{yr}^{-1}$. Before entering the Sudan plains, the Blue Nile receives 14 major torrential tributaries which supply most of the silty river water received at Roseires reservoir (Omer et al. 2015).

The discharge of the Blue Nile is primarily affected by the seasonality of torrential rains on the Ethiopian highlands where a wet season extends from July to October, with maximum rainfall and river flow during August-September, and a dry season from November to June.

The natural flow of the Blue Nile has been altered by artificial hydrological regimes within Sudan. Sennar and Roseires dams were built across the Blue Nile in 1925 and 1966 respectively. Roseires reservoir $(629 \mathrm{~km}$ upstream Khartoum, $11^{\circ} 48^{\prime} 26^{\prime \prime}$ and $11^{\circ} 32^{\prime} 45^{\prime \prime} \mathrm{N}$ and $34^{\circ} 26^{\prime} 46^{\prime \prime}$ and $\left.34^{\circ} 28^{\prime} 33^{\prime \prime} \mathrm{E}\right)$ is located in southeast of Sudan in Blue Nile State. Sennar reservoir $(345 \mathrm{~km}$ upstream Khartoum, $13^{\circ} 32^{\prime} 55^{\prime \prime}$ and $13^{\circ} 24^{\prime} 59^{\prime \prime} \mathrm{N}$ and $33^{\circ} 38^{\prime} 05^{\prime \prime}$ and $33^{\circ} 39^{\prime} 53^{\prime \prime} \mathrm{E}$ ) is located north of Roseires in Sennar State (Figure 1).

These two dams altered the natural flow of the river. A heightening of Roseires Dam was completed in January 2013. The project added $10 \mathrm{~m}$ in height and $12 \mathrm{~km}$ in length to the existing dam, increasing its storage capacity from $3.0 \times 10^{9} \mathrm{~m}^{3}$ to $7.4 \times 10^{9} \mathrm{~m}^{3}$ and its storage time from 45 to 60 days. The reservoir has a maximum depth of $45 \mathrm{~m}$. The storage capacity of Sennar Dam is $1 \times 10^{9} \mathrm{~m}^{3}$ with a retention time of 32 days. Sennar reservoir has a maximum depth of $17 \mathrm{~m}$. In 2017 Roseires reservoir reached its full capacity by late-December (Roseires and Sennar dams Engineers, Personal communication).

Figure 1. Map of the Blue Nile within Sudan Plains Showing Locations of Roseires and Sennar Dams

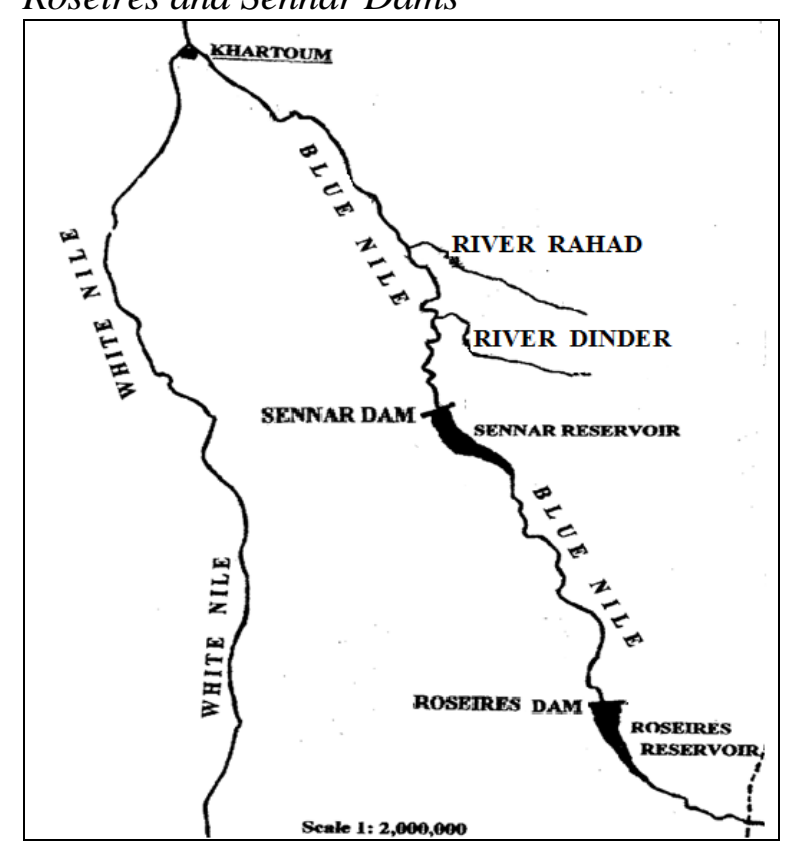




\section{Literature Review}

\section{The Blue Nile Upstream of Roseires before Construction of the Dam}

Before the completion of Roseires Dam, Hammerton (1970a, b, 1971a), in three different surveys carried out during February 1964, February 1965 and February 1966 reported an extremely sparse plankton population in $400 \mathrm{~km}$ section of the river upstream of Sennar reservoir. He found within this stretch of the Nile that the diatom Aulacoseira (formerly Melosira) granulata and the cyanobacterium Anabaena flos-aquae - two principal components of the Blue Nile plankton north of Sennar reservoir - were present in very small numbers (around 20 cells $\mathrm{mL}^{-1}$ ). All samples collected during 1964 - 1966 contained visible quantities of silt and fine sand and some organic detritus with a Secchi disc visibility less than $50 \mathrm{~cm}$. Poor light penetration coupled with relatively high current velocity might be the sole factor checking the development of phytoplankton within this stretch of the Blue Nile before the construction of Roseires Dam (Hammerton 1970a, b, 1971a, Talling and Rźoska 1967).

\section{Sennar Reservoir before Construction of Roseires Dam}

Hammerton (1970a, b, 1971a) confirming the findings of Talling and Rźoska (1967) found that as the water enters Sennar reservoir, most of the silt settled out. The Secchi disc visibility increased considerably resulting in a dense phytoplankton development within the reservoir. The diatom Aulacoseira granulata increased from around 20 cells $\mathrm{mL}^{-1}$ before entering Sennar reservoir to $2.1 \times 10^{3}$ cells $\mathrm{mL}^{-1}$ in the reservoir. There was a similar increase in numbers of the cyanobacterium Anabaena flos-aquae.

Roseires Reservoir: The Development of Phytoplankton after Construction of the Dam in 1966

According to Hammerton (1971a, b, c) the phytoplankton in Roseires reservoir during the first three years of its filling (1966 - 1970) showed considerably heavy growth with Aulacoseira granulata, Microcystis flos-aquae, Anabaena flos-aquae, Phormidium mucicola, Volvox aureus, and Pediastrum simplex var. duodenarium dominating the plankton at one time or another. The diatom Aulacoseira granulata increased from around 20 cells $\mathrm{mL}^{-1}$ before entering Roseires reservoir to $5.2 \times 10^{3}$ cells $\mathrm{mL}^{-1}$ cells $\mathrm{mL}^{-1}$ in the reservoir.

\section{Sennar Reservoir after Construction of Roseires Dam}

Hammerton (1971c, d, 1972a) followed the seasonal cycles of the phytoplankton in Sennar reservoir for three consecutive seasons. During 1968 1970 Aulacoseira granulata and co-dominant Anabaena flos-aquae dominated the phytoplankton in the reservoir. The total algal densities in Sennar reservoir were higher than those in Roseires. 
The fluctuations in the densities of Aulacoseira and Anabaena within Sennar reservoir during 1968 - 1970 closely reflected the seasonal changes of the numbers of these organisms in Roseires reservoir. The Roseires reservoir shortly after its creation greatly influenced the phytoplankton composition and density within Sennar reservoir, and subsequently downstream.

The Development of Phytoplankton at Khartoum (latitude $16^{\circ} \mathrm{N}$ ) before and after Construction of the Dam

For logistic reasons, studies of the phytoplankton of the Blue Nile during 1950s were confined to Khartoum. Prior to the establishment of Roseires Dam, Brook (1954), Rźoska et al. (1955), Talling and Rźoska (1967) reported a definite cycle and seasonal peaks of the major phytoplankton species that could be faithfully predicted at Khartoum. Later, after the construction of Roseires Dam, Sinada and Abdel Karim, (1984a), Yousif (2004) and Sinada and Yousif (2012) confirmed the recurrent substantial increase in algal densities which always appeared in the Blue Nile at Khartoum after the flood period in late October/early November when the current subsided and most of the silt settled out. These recurrent algal peaks were no different from those reported at Khartoum before the construction of Roseires Dam by previous workers except for the appearance of new records, with the dominant algal species remaining the same.

\section{Materials and Methods}

\section{Study Period}

The two reservoirs were visited every two - four months, thus, December 2015, February 2016, April 2016, November 2016, April 2017 and December 2017. No attempt was made to sample the reservoirs during the rainy flood season between June - October 2016 and June - October 2017 since no alga was expected to be encountered in any numbers in the expected highly turbid flood waters. To assess spatial distribution of phytoplankton communities and water quality, surface samples only were collected on one occasion from five randomly chosen stations covering only the central sector of each reservoir. The vertical distribution of phytoplankton populations and physico-chemical variables were assessed only in Roseires reservoir at the central station. A 2-L Ruttner water sampler connected to a $45 \mathrm{~m}$ steel cable was lowered from the side of a tugboat using a manual winch with automatic brake to collect water from the surface, $15 \mathrm{~m}$ and near the bottom. All water samples were collected between 09:00 and 10:00 am. Only surface samples were collected from Sennar reservoir because it was not safe to use the heavy winch to retrieve the $2-\mathrm{L}$ Ruttner sampler from the side of a small powermotorized fishing boat. 


\section{Water and Phytoplankton Sampling}

Surface water samples were collected from each reservoir in polyethylene bottles. Depth profiles were studied only in Roseires reservoir. $\mathrm{pH}$ and electric conductivity were recorded in situ onboard using handheld Jenway digital field instruments. Water temperature was measured using a mercury thermometer. Water transparency was measured using a Secchi disc. Alkalinity was determined by titration with $0.1 \mathrm{~N} \mathrm{HCl}$ in the field using bromcresol green-methyl red mixed indicators as described by Mackereth et al. (1978).

For analysis of dissolved nitrate-nitrogen $\left(\mathrm{NO}_{3}-\mathrm{N}\right)$, phosphate-phosphorus $\left(\mathrm{PO}_{4}-\mathrm{P}\right)$ and heavy metals, water samples were collected in clean polyethylene bottles and transported to the laboratory. Silica $\left(\mathrm{SiO}_{2}\right)$ was determined on one occasion only (20.3 and $23.1 \mathrm{mg} \mathrm{SiO}_{2} \mathrm{~L}^{-1}$ in Sennar and Roseires reservoirs respectively). Water samples were analyzed by the spectrophotometric procedure as described in Allen (1989) using Apel Spectrophotometer, Japan, fitted with a 1 $\mathrm{cm}$ path length cuvette. The absorbance was measured at 540, 880, and $810 \mathrm{~nm}$, for the $\mathrm{NO}_{3}, \mathrm{PO}_{4}$, and $\mathrm{SiO}_{2}$, respectively. Sodium and potassium were determined following the flame photometer method. Calcium was measured following the EDTA titration method. Cadmium, cobalt, chromium, copper, iron, lead, magnesium, manganese, and zinc were measured on three occasions. Analysis was performed on AA-6800 Shimadzu Atomic Absorption Spectrophotometer (Shimadzu Corporation, Japan). A linear calibration curve for each trace metal was drawn by preparing sets of external standards diluted from 1000 ppm certified single element reference solutions supplied by Romil (Romil, Ltd, Cambridge, UK). A standard QC solution was analyzed after 10 samples for each of the nine trace metals.

\section{Qualitative and Quantitative Analyses of Phytoplankton}

For qualitative taxonomic analysis, phytoplankton samples were collected with plankton net (mesh size $25 \mu \mathrm{m}$ ). The net samples were transferred into plastic containers with screw caps. Each sample was preserved in $4 \%$ formalin and stored in the laboratory until analysis.

For quantitative analysis of the phytoplankton, unstrained water samples were collected from below the surface. They were fixed and preserved with $10 \%$ Lugol's solution. Depending on the density of the phytoplankton, aliquots of 1-10 $\mathrm{mL}$ were sedimented in chambers by standing for $2-5 \mathrm{~h}$ following the procedure described by Lund et al. (1958). Algae present were enumerated on a Zeiss inverted microscope at a magnification of $\times 200$. Each filament was counted as a unit. The average number of cells per filament was determined from a large number of specimens. Results of phytoplankton biomass were expressed as cells $\mathrm{mL}^{-1}$.

Phytoplankton biomass was measured in terms of Chlorophyll- $a(\mathrm{Chl}-a)$ as described in Strickland and Parsons (1977). For the estimation of total chlorophyll- $a$ a known amount of surface water was filtered through GF/C filter. The filter was removed and the chlorophyll was extracted in a flask with $14 \mathrm{~mL}$ of 
$90 \%$ acetone for $24 \mathrm{~h}$ at $4^{\circ} \mathrm{C}$ in the dark. The clear extract was transferred to a 1 $\mathrm{cm}$ path length cuvette using Apel Spectrophotometer, Japan, to measure the absorbance at 665 and $750 \mathrm{~nm}$.

\section{Identification of Planktonic Algae}

Algae collected in the net samples were identified up to genus or species level according to the standard works and keys of Cleve-Euler (1951), Desikachary (1959), Prescott (1962), Krammer (1991a, b), Wehr et al. (2015).

\section{Statistical Analysis}

The differences in physical and chemical variables between the two reservoirs were tested using $\mathrm{T}$ test at $95 \%$ Confidence Intervals. The homogeneity of water in each reservoir was tested by calculating the coefficient of variation.

\section{Results and Discussion}

Water Quality: Physical and Chemical Variables

The waters of Sennar and Roseires reservoirs are of excellent quality for drinking and domestic use, irrigation, industrial use, navigation, tourism, bathing and recreation. In Sennar and Roseires reservoirs the water quality and heavy metal concentrations in terms of cadmium, chromium, copper, iron, lead, manganese, and zinc were well within allowable limits set by the Sudanese Standards and Metrology Organization (SSMO 2008) and are within permissible limits set by WHO for drinking water (WHO 2011).

The concentrations of heavy metals were more or less the same in the two reservoirs except for slightly higher but not alarming value of chromium recorded once in Roseires reservoir. Conversely, manganese was slightly higher in Sennar reservoir than in Roseires. The source of the heavy metals detected in waters of the two reservoirs is more likely to be natural since no anthropogenic polluting activities such as factories occur in the vicinity of the two reservoirs.

Physical and chemical variables measured in water samples collected from the sampling sites in both reservoirs are presented in Tables 1 and 2. The statistical analysis using t-test with $95 \%$ Confidence Intervals shows that there were no significant differences between the samples taken from Sennar and Roseires reservoirs as regards the following environmental variables: electrical conductivity, alkalinity, nitrate-nitrogen, and phosphate-phosphorus. Similarly, $\mathrm{pH}$ which was neither acidic nor highly alkaline was more or less the same in both reservoirs.

Table 1 shows the results of physico-chemical analysis in both reservoirs. The concentrations of $\mathrm{NO}_{3}-\mathrm{N}$ and $\mathrm{PO}_{4}-\mathrm{P}$ measured in both reservoirs during the present study were persistently higher than those recorded by previous workers at Khartoum. For instance in April 2016 and April 2017 the concentrations of $\mathrm{NO}_{3}$ 
$\mathrm{N}$ and $\mathrm{PO}_{4}-\mathrm{P}\left(326-550 \mu \mathrm{g} \mathrm{NO} \mathrm{NO}_{3}-\mathrm{N} \mathrm{L}^{-1}\right.$ and $\left.80-160 \mu \mathrm{g} \mathrm{PO}_{4}-\mathrm{P} \mathrm{L}^{-1}\right)$ were exceptionally high to be monitored during this time of the year. In the past 60 years $\mathrm{NO}_{3}-\mathrm{N}$ and $\mathrm{PO}_{4}-\mathrm{P}$ in the Blue Nile at Khartoum during April were severely depleted by heavy phytoplankton growth to less than $29 \mu \mathrm{g} \mathrm{NO} \mathrm{NO}_{3}-\mathrm{N} \mathrm{L}^{-1}$ and undetectable $\mathrm{PO}_{4}-\mathrm{P}$ levels (Talling and Rźoska 1967, Hammerton 1972b, Sinada and Abdel Karim 1984b, Sinada and Yousif 2013). The high concentrations of nutrients measured in the two reservoirs during the present study is attributed to the paucity of phytoplankton which was indicated by very low numbers of algal counts in the two reservoirs (see later).

Vertical Distribution of the Physical and Chemical Variables in the Roseires Reservoir

Water samples were retrieved from the surface, $15 \mathrm{~m}$ and from near the bottom $(\sim 44 \mathrm{~m})$ in the Roseires reservoir only. The three depths were sampled on five occasions during the present study. As Table 2 shows, a weak, possibly unstable, thermal stratification was detected on 26 April 2016. No stratification was observed during the other sampling visits. Temperature, $\mathrm{pH}$, alkalinity, and conductivity remained more or less uniformly distributed throughout the water column. Absence of stratification is attributable to the small water temperature difference between summer and winter in Roseires area. Perhaps wind action was strong enough to mix the water and destroy any stratification.

Spatial Distribution of the Physical and Chemical Variables in the Two Reservoirs

An attempt was made to determine the spatial distribution of the physical and chemical variables in the two reservoirs by sampling five locations in each reservoir. The Coefficient of variation values of $<0.3$ indicate that there are no significant differences in physical and chemical variables among the sampling sites in Sennar or those in Roseires reservoir. The environmental variables measured were more or less evenly distributed in the various sampling sites in each reservoir (not shown here).

Phytoplankton Species Diversity

Qualitative Results

List of algae present in the plankton of Sennar and Roseires reservoirs and their occurrence at different sampling dates are given in Table 3. Five phytoplankton groups were represented in the two reservoirs though in very small numbers. These groups were Bacillariophyta, Cyanobacteria, Chlorophyta, Euglenophyta, and Pyrrophyta. Bacillariophyta were qualitatively dominant, while Cyanobacteria were subdominant in the two reservoirs.

A total of 39 taxa were encountered in the plankton of the two reservoirs during the present study. In terms of species, Bacillariophyta were the richest taxonomic group with 17 taxa, followed by Cyanobacteria (11 taxa), Chlorophyta (7 taxa), Euglenophyta (3 taxa), and Pyrrophyta (1 taxon). As expected, the species composition was more or less similar in both reservoirs. 
Table 1. Physical and Chemical Variables Recorded in Surface Waters Collected from Sennar and Roseires Reservoirs during the Study Period

\begin{tabular}{|c|c|c|c|c|c|c|c|c|c|c|}
\hline \multirow[b]{2}{*}{ Physico-chemical variables } & \multicolumn{5}{|c|}{ Sennar reservoir } & \multicolumn{5}{|c|}{ Roseires reservoir } \\
\hline & $\begin{array}{c}\text { Feb } \\
2016\end{array}$ & $\begin{array}{c}\text { Apr } \\
2016\end{array}$ & $\begin{array}{l}\text { Nov } \\
2016\end{array}$ & $\begin{array}{c}\text { Apr } \\
2017\end{array}$ & $\begin{array}{c}\text { Dec } \\
2017\end{array}$ & $\begin{array}{c}\mathrm{Feb} \\
2016\end{array}$ & $\begin{array}{c}\text { Apr } \\
2016\end{array}$ & $\begin{array}{c}\text { Nov } \\
2016\end{array}$ & Apr 2017 & Dec 2017 \\
\hline Temperature $\left({ }^{\circ} \mathrm{C}\right)$ & 22.0 & 30.0 & 27.6 & 29.8 & 24.8 & 26.6 & 29.2 & 30.3 & 27.8 & 26.3 \\
\hline Secchi transparency $(\mathrm{cm})$ & 15 & 45 & 15 & 70 & 60 & 30 & 100 & 35 & 100 & 85 \\
\hline Conductivity $\left(\mu \mathrm{Scm}^{2}\right)$ & 113 & 122 & 110 & 159 & 120 & 111 & 120 & 101 & 155 & 121. \\
\hline $\mathrm{pH}$ (Units) & 8.4 & 7.8 & 7.9 & 7.8 & 8.0 & 8.4 & 8.0 & 7.9 & 7.7 & 8.5 \\
\hline Alkalinity $\left(\mathrm{meq} \mathrm{L} \mathrm{L}^{-1}\right)$ & 3.20 & 3.12 & 3.20 & 2.00 & 1.3 & 3.12 & 3.20 & 3.04 & 1.90 & 1.2 \\
\hline $\mathrm{NO}_{3}-\mathrm{N}\left(\mu \mathrm{g} \mathrm{L}^{-1}\right)$ & 350 & 520 & 442 & 355 & 500 & 377 & 550 & 348 & 326 & 440 \\
\hline $\mathrm{PO}_{4}-\mathrm{P}\left(\mu \mathrm{g} \mathrm{L}^{-1}\right)$ & 160 & 140 & 110 & 90 & 50 & 150 & 160 & 70 & 80 & 70 \\
\hline Sodium $(\mathrm{mg} / \mathrm{L})$ & - & 6.8 & 6.4 & 7.4 & - & 6.5 & 6.3 & 6.4 & 7.1 & - \\
\hline Potassium (mg/L) & - & 4.9 & 2.6 & 4.5 & - & 2.9 & 4.7 & 2.2 & 4.7 & - \\
\hline Calcium (mg/L) & 15.7 & - & 16.7 & 19.4 & 7.5 & 12.9 & - & 14.7 & 18.2 & 5.9 \\
\hline Magnesium (mg/L) & 34.4 & - & - & 24.0 & 22.9 & 33.2 & - & - & 32.0 & 30.8 \\
\hline Cadmium $\left(\mu \mathrm{g} \mathrm{L}^{-1}\right)$ & 1.0 & - & - & ND & ND & 0.5 & - & - & ND & ND \\
\hline Chromium $\left(\mu \mathrm{g} \mathrm{L}^{-1}\right)$ & 22.8 & - & - & ND & 12.5 & 32.6 & - & - & ND & 58.3 \\
\hline Cobalt $\left(\mu \mathrm{g} \mathrm{L}^{-1}\right)$ & 18.0 & - & - & 60.0 & ND & 21.6 & - & - & 79.0 & ND \\
\hline Copper $\left(\mu \mathrm{g} \mathrm{L}^{-1}\right)$ & 24.2 & - & - & 7.0 & 18.2 & 24.2 & - & - & 6.0 & 18.2 \\
\hline Ferrous $(\mathrm{mg} / \mathrm{L})$ & 0.2 & - & - & 0.38 & 0.29 & 0.1 & - & - & 0.20 & 0.64 \\
\hline Lead $\left(\mu \mathrm{g} \mathrm{L}^{-1}\right)$ & ND & - & - & ND & ND & ND & - & - & 8 & ND \\
\hline Manganese $\left(\mu \mathrm{g} \mathrm{L}^{-1}\right)$ & 4.2 & - & - & ND & 8.9 & 13.6 & - & - & ND & 11.5 \\
\hline Zinc $\left(\mu \mathrm{g} \mathrm{L}^{-1}\right)$ & 2.1 & - & - & 1.2 & ND & 2.9 & - & - & ND & 3.9 \\
\hline Chlorophyll-a $\left(\mu \mathrm{g} \mathrm{L}^{-1}\right)$ & ND & ND & ND & ND & $>1$ & ND & ND & ND & ND & ND \\
\hline
\end{tabular}

$\mathrm{ND}=$ Not Detected. 
Table 2. Physical and Chemical Data Recorded in Waters Collected from Three Depths in Roseires Reservoir during the Periods February 2016, April 2016, November 2016, April 2017 and December 2017

\begin{tabular}{|c|c|c|c|c|c|c|}
\hline \multirow{2}{*}{$\begin{array}{c}\text { Environmental } \\
\text { variables }\end{array}$} & \multirow{2}{*}{$\begin{array}{l}\text { Depth } \\
\text { (m) }\end{array}$} & \multicolumn{5}{|c|}{ Roseires reservoir } \\
\hline & & $\begin{array}{c}\text { Feb } \\
2016 \\
\end{array}$ & $\begin{array}{c}\text { Apr } \\
2016 \\
\end{array}$ & $\begin{array}{l}\text { Nov } \\
2016\end{array}$ & $\begin{array}{c}\text { Apr } \\
2017 \\
\end{array}$ & $\begin{array}{l}\text { Dec } \\
2017 \\
\end{array}$ \\
\hline \multirow{3}{*}{ Temperature $\left({ }^{\circ} \mathrm{C}\right)$} & surface & 26.6 & 29.2 & 30.3 & 27.8 & 26.3 \\
\hline & 15 & 28.2 & 29.1 & 30.0 & 27.8 & 26.4 \\
\hline & 44 & 25.1 & 28.5 & 29.7 & 28.0 & 27.8 \\
\hline \multirow{3}{*}{$\begin{array}{l}\text { Conductivity } \\
\qquad\left(\mu \mathrm{Scm}^{2}\right)\end{array}$} & surface & 111 & 120 & 101 & 276 & 213 \\
\hline & 15 & 111 & 120 & 115 & 276 & 214 \\
\hline & 44 & 113 & 122 & 117 & 281 & 215 \\
\hline \multirow{3}{*}{ pH (Units) } & surface & 8.4 & 8.0 & 7.9 & 7.7 & 8.5 \\
\hline & 15 & 8.2 & 8.1 & 7.9 & 7.1 & 8.1 \\
\hline & 44 & 8.5 & 8.0 & 7.8 & 7.2 & 8.1 \\
\hline \multirow{3}{*}{$\begin{array}{l}\text { Alkalinity } \\
\left(\text { meq L L }^{-1}\right)\end{array}$} & surface & 3.12 & 3.20 & 3.04 & 1.90 & 1.20 \\
\hline & 15 & 3.0 & 1.95 & 1.50 & 1.90 & 1.30 \\
\hline & 44 & 3.0 & 3.38 & 1.50 & 1.90 & 1.40 \\
\hline
\end{tabular}

Aulacoseira was represented by A. distans, A. granulata, A. granulata var. angustissima, $A$. agassizii, and a species identified tentatively as $A$. ambigua?. The diatom community structure is similar to that observed by Sinada and Yousif (2012) in the Blue Nile at Khartoum. This may indicate that the inocula of the recurrent annual Aulacoseira peaks recorded at Khartoum originate from the upper reaches of the Blue Nile. Other diatoms recorded in the two reservoirs were also rarely seen in the net samples during the present study (Table 3).

Cyanobacteria were represented in the two reservoirs by Anabaena flos-aquae f. spiroides, Aphanocapsa sp., Aphanotheca sp., Chroococcus sp., Gloeotrichia sp., Merismopedia sp., Microcystis aeruginosa, Microcystis incerta, Oscillatoria spp., and Rivularia sp. These Cyanobacteria were rarely seen in the net samples collected from both reservoirs. Anabaena flos-aquae f. spiroides and Microcystis aeruginosa were common in the Blue Nile at Khartoum often developing profuse growth during December - February (Sinada unpublished data, Sinada and Yousif 2012). Gloeotrichia echinulata and Rivularia sp. which occurred on different occasions in the two reservoirs were not reported before in the Nile within Sudan.

Chlorophyta was represented by seven taxa in the plankton. These species were rarely seen in the net samples.

Euglenophyta was represented by two species of Trachelomonas and one species of Euglena while Pyrrophyta was represented by one species of Glenodinium (Table 3).

\section{Quantitative Results}

Unlike conditions observed during 1967 - 1970 by Hammerton (1971c, d, 1972a) no single algal species was dominant during the present study. Algal numbers were present in extremely unexpected low numbers in both Reservoirs throughout the study period. Although encountered in very small numbers, it is striking to record 15 algal taxa in Sennar reservoir at the end of the study in December 2017, while no alga was seen in the net samples collected from 
Roseires reservoir during the same visit. In general, more algal taxa were collected from Sennar reservoir (32 taxa) than from Roseires reservoir (22 taxa). Although needs to be verified by intensive sampling in selected stretches of the Blue Nile between the tail of Sennar reservoir and Roseires Dam, it may be assumed that not all inocula of algal taxa in Sennar Dam and downstream to Khartoum originate from Roseires reservoir.

Glenodinium sp. appeared only in Sennar reservoir in December 2017 exhibiting the highest count of 36 cells $\mathrm{mL}^{-1}$ exceeding those of Aulacoseira granulata. The same species of Glenodinium was reported in the Blue Nile at Khartoum by Sinada (1972) and Sinada and Yousif (2012) though in negligible numbers.

Aulacoseira granulata which was dominant in the two reservoirs throughout the growth seasons (November - May) of 1966 - 1970 showing peaks in the range of $1.5 \times 10^{3}-1.2 \times 10^{4}$ cells $\mathrm{mL}^{-1}$ (Hammerton 1971c, d, 1972a), rarely exceeded 20 cells $\mathrm{mL}^{-1}$ during the present study. Similarly, Table 3 shows that Anabaena flosaquae, which co-dominated the phytoplankton in the two reservoirs throughout much of the growing seasons during 1966-1970 was rarely seen during the present study. The conditions during the present study were reminiscent of the phytoplankton population in $400 \mathrm{~km}$ section of the river upstream of Sennar reservoir reported by Talling and Rźoska (1967) before the construction of Roseires Dam where Aulacoseira granulata and Anabaena flos-aquae, numbers did not exceed 20 cells $\mathrm{mL}^{-1}$ before entering Sennar reservoir.

The scarcity of planktonic algae in Sennar and Roseires reservoirs during the study period, despite of high nutrient concentrations may be attributed to the unusual high silt content. It is obvious that poor light penetration is the sole factor checking the development of phytoplankton in the two reservoirs during the present study. These conditions in the two reservoirs were no different from those reported in the Blue Nile at Khartoum during the annual phase of the flood period by several workers including Sinada and Abdel Karim (1984a, b) and Sinada and Yousif (2012).

According to Hammerton (1971c, d, 1972a), Roseires reservoir shortly after its construction greatly influenced the phytoplankton composition and density within Sennar reservoir; the total algal biomass in Sennar reservoir was higher than that in Roseires reservoir. However, in the present study the meagre data show that more algal taxa and relatively higher algal counts occurred in Sennar than in Roseires reservoir. No influence is exerted by Roseires Dam on Sennar reservoir during the present study except perhaps the discharge of silty water which decreased Secchi transparency in Sennar reservoir preventing the development of phytoplankton. 
Table 3. List of the Planktonic Algae Encountered in Net Samples Collected from Sennar and Roseires Reservoirs: (+) Rare, and (-) Absent. Numbers Indicate Algal Biomass in terms of Cells or Coils per mL Encountered in Surface Samples Collected from the Central Stations in Sennar and Roseires Reservoirs

\begin{tabular}{|c|c|c|c|c|c|c|c|c|c|c|c|c|}
\hline \multirow[b]{2}{*}{ Species } & \multicolumn{6}{|c|}{ Sennar reservoir } & \multicolumn{6}{|c|}{ Roseires reservoir } \\
\hline & $\begin{array}{c}\text { Dec } \\
2015 \\
\end{array}$ & $\begin{array}{l}\mathrm{Feb} \\
2016\end{array}$ & $\begin{array}{c}\text { Apr } \\
2016\end{array}$ & $\begin{array}{l}\text { Nov } \\
2016\end{array}$ & $\begin{array}{c}\text { Apr } \\
2017\end{array}$ & $\begin{array}{c}\text { Dec } \\
2017\end{array}$ & $\begin{array}{c}\text { Dec } \\
2015\end{array}$ & $\begin{array}{l}\text { Feb } \\
2016\end{array}$ & $\begin{array}{c}\text { Apr } \\
2016\end{array}$ & $\begin{array}{l}\text { Nov } \\
2016\end{array}$ & $\begin{array}{c}\text { Apr } \\
2017\end{array}$ & $\begin{array}{c}\text { Dec } \\
2017\end{array}$ \\
\hline Pandorina morum (O. Müller) Bory & - & - & - & - & - & - & - & + & - & - & - & - \\
\hline P. simplex var. duodenarium (Bailey) Rabenhorst & + & - & - & - & + & - & - & - & - & - & - & - \\
\hline Pediastrum obtusum Lucks & - & - & - & - & - & + & - & - & - & - & - & - \\
\hline Scenedesmus sp. & - & - & - & - & - & 4 & - & - & - & - & - & - \\
\hline Schroederia setigera (Schröder) Lemmermann & - & - & - & - & - & 4 & - & - & - & - & - & - \\
\hline Staurastrum sp. & - & - & + & - & + & - & - & - & - & - & - & - \\
\hline Volvox aureus Ehrenberg & - & - & - & - & - & - & - & - & - & + & - & - \\
\hline Aulacoseira ambigua? (Grunow) Simonsen & + & + & + & + & + & + & - & - & - & + & - & - \\
\hline Aulacoseira distans (Ehrenberg) Simonsen & - & + & - & + & + & 16 & - & + & - & + & - & - \\
\hline Aulacoseira granulata (Ehrenberg) Simonsen & - & 2 & 2 & - & + & 24 & - & + & 4 & + & + & - \\
\hline A. granulata var. angustissima (O. Müller) Simonsen & + & + & + & - & + & + & + & - & + & + & + & - \\
\hline Aulacoseira agassizii (Ostenfeld) Simonsen & - & - & - & - & - & + & - & - & - & - & - & - \\
\hline Cyclotella meneghiniana Kuetz & - & 1 & - & - & - & 4 & - & + & - & - & - & - \\
\hline Gomphonema sp. & - & - & - & + & - & 4 & - & - & - & + & - & - \\
\hline Caloneis amphisbaena (Bory) Cleve & - & + & - & + & - & - & - & - & - & - & - & - \\
\hline Navicula spp & + & - & - & - & - & 4 & + & + & - & - & - & - \\
\hline Nitzschia sp. & - & - & - & - & - & - & - & + & - & - & - & - \\
\hline Pleurosigma sp. & - & - & - & + & - & - & - & - & - & - & + & - \\
\hline $\begin{array}{l}\text { Rhopalodia gibba (Ehrenberg) O. Müller } \\
\text { Ulnaria(formerly Synedra) acus(Kützing) M. Aboal }\end{array}$ & - & - & + & + & - & - & - & - & - & - & + & - \\
\hline Ulnaria acus (Kützing) M. Aboal & - & - & + & - & - & 4 & - & - & - & - & + & - \\
\hline Ulnaria ulna (Nitzsch) Compère & - & - & - & - & - & + & - & - & - & - & - & - \\
\hline Nitzschia sp. & - & - & - & - & - & - & - & + & - & - & - & - \\
\hline Surirella tenera Gregory. & - & - & - & + & - & - & - & - & - & + & - & - \\
\hline Cymatopleurasolea (Bréb.) W. Smith & - & - & - & + & - & - & - & - & - & - & - & - \\
\hline
\end{tabular}




\begin{tabular}{|c|c|c|c|c|c|c|c|c|c|c|c|c|}
\hline Anabaena flos-aquae (Lyngbye) Brébisson f. spiroides & + & - & 2 & - & - & 8 & - & + & - & - & - & - \\
\hline Anabaena spp. & - & - & - & + & - & - & - & - & - & - & - & - \\
\hline Aphanocapsa sp. & - & + & - & - & + & - & - & ++ & - & - & + & - \\
\hline Aphanotheca sp. & - & - & - & - & + & - & - & + & - & - & + & - \\
\hline Chrococcus sp. & - & - & - & - & - & + & - & - & - & - & - & - \\
\hline Merismopedia tenuissima Lemmer & - & - & - & + & - & - & - & + & - & - & - & - \\
\hline Gloeotrichia echinulata P.G.Richter & - & - & + & - & - & - & - & + & - & - & - & - \\
\hline Microcystis aeruginosa( Kützing) Elenkin & - & - & - & - & - & - & - & + & - & - & - & - \\
\hline Microcystis incerta(Lemmer.) Lemmerman & - & - & - & - & - & 4 & - & - & - & - & - & - \\
\hline Oscillatoria spp. & - & + & - & + & - & - & - & ++ & - & - & - & - \\
\hline Rivularia sp. & - & - & + & - & - & - & - & - & + & - & - & - \\
\hline Euglena sp. & - & - & - & - & - & 4 & - & - & - & - & - & - \\
\hline Trachelomonas volvocina (Ehrenb.) Ehrenberg & - & - & - & - & - & 4 & - & - & - & - & - & - \\
\hline Trachelomonas sp. & - & - & - & - & - & + & - & - & - & - & - & - \\
\hline Glenodinium sp. & - & - & - & - & - & 36 & - & - & - & - & - & - \\
\hline
\end{tabular}




\section{Discussion}

The construction of Roseires Dam in 1966, as expected, had its influence upon the ecology of the Blue Nile within Sudan by changing the hydrological regime of the river and creating a reservoir in which current velocity was much reduced and lake conditions were initiated. Previous workers reported major changes in the species composition of the phytoplankton at Khartoum after the construction of Roseires Dam when certain taxa, which dominated the phytoplankton in the 1950s, disappeared and new species appeared in appreciable numbers in early 1970s and by the turn of the century.

Shortly after the construction of Roseires Dam in 1966, seasonal peaks of the major phytoplankton species were well established and a definite annual cycle could be faithfully predicted at Khartoum. The recurrent annual biological cycles of events in the Blue Nile are greatly influenced by the flood regime and the storage of water in Roseires and Sennar reservoirs, which are controlled by the natural regime of rainfall in the catchment area on the Ethiopian Plateau.

Rźoska et al. (1955), Talling and Rźoska (1967), Sinada (1972), Sinada and Abdel Karim (1984a, b) and Yousif (2004) showed that the annual flood of the Blue Nile is the most important factor limiting the growth of the phytoplankton at Khartoum. The scarcity of planktonic algae during the flood between late June and late October despite of high nutrient concentrations is attributable to the high silt content and poor light penetration. It has been well established that at Khartoum, diatoms (Aulacoseira spp.) were the first to appear in appreciable numbers after the flood, and dominate the phytoplankton during November-December to be replaced successively by peaks of profuse growth of Microcystis and Anabaena during January-February. During March-April green algae preponderated, followed by the recurrent summer maximum of Aulacoseira and Anabaena in May to mid-June before being washed out by the new brown floodwater (Rźoska et al. 1955, Talling and Rźoska 1967, Sinada 1972, Sinada and Abdel Karim 1984a, b, Yousif 2004). We assumed that similar cycles of phytoplankton succession would continue to occur every year in Roseires and Sennar reservoirs and along the whole stretch of the Blue Nile from Sennar to Khartoum as long as the hydrological regime of the river was not significantly altered.

Indeed, throughout the years since the construction of Roseires Dam in 1966 no unusual incidence, which could be confirmed by microscopic examination and sediment load, has been reported except in May 2003 and January 2009. In these two incidents, unprecedented profuse growth of the cyanobacterium Anabaena flos-aquae, attributed with caution to incipient eutrophication, occurred in the Blue Nile at Khartoum and along the whole stretch of the Blue Nile from Khartoum to Sennar Dam. Otherwise, there was a definite highly predictable phytoplankton cycle which almost faithfully repeated itself every year since the construction of Roseires Dam in 1966.

However, an unusual event, which was a deviation from the repeated and predictable cycle, occurred during the present study in 2016-2017. We expected that algae in Roseires and Sennar dams and at Khartoum should have started to appear in late October-early November 2015 (when most of the silt should have 
settled downs and water should have become clear) as they faithfully did for the last fifty years since the construction of Roseires Dam. Nevertheless, algae did not appear let alone in large numbers as we expected. Unlike conditions observed by Hammerton (1971a, b, c, 1972a) after the construction of Roseires Dam, throughout the period of the present study, visible quantities of silt and fine sand remained suspended in the water column of the two reservoirs as well as water samples collected from the Blue Nile at Khartoum. The river at Khartoum did not support any appreciable algal growth while turbidity and concentrations of nutrients remained unexpectedly high and continued to be high with no signs of any algal growth during 2016 and 2017. These conditions, which prevailed throughout the present study, are reminiscent of the annual flood season at Khartoum during late June-early October. A plausible explanation for the paucity of algae in Sennar, Roseires, and at Khartoum during December 2015-April 2016 was deduced from briefings given by the engineers of Roseires Dam. They briefed us of a different filling system they had adopted during 2015 flood season (JulySeptember) because of low magnitude of flow at El Deim (a monitoring station upstream Roseires reservoir near the Sudanese-Ethiopian border) due to little rainwater received in Ethiopia- the lowest annual rainfall in 30 years. The filling of the reservoir of Roseires Dam started unusually as early as August 2015 - a deviation from operation rules under normal climatic conditions in which filling never started before 1st September or after 26th September each year when most of the silty water was allowed to flow downstream. Possibly the unusual early damming of the highly turbid water in August 2015 contributed to storage of unprecedented large volumes of water, which contain large amounts of silt. Engineers at Roseires and Sennar dams opened the spillways during November and December 2015 to allow the highly turbid water stored in the Roseires reservoir to pass downstream to compensate for shortage of water at Merowe Dam $350 \mathrm{~km}$ north of Khartoum. This seems to be a plausible explanation for the unprecedented turbid water reaching Khartoum during December 2015 - April 2106. The absence of algae in the Blue Nile at Khartoum during November 2015 April 2016 was attributed to the flow of turbid water which did not allow silt to settle out of suspension thus preventing the growth of algae.

Similar conditions of paucity of algae were observed during sampling visits to Sennar and Roseires reservoirs in April 2017 and December 2017. By late December 2017, the Roseires reservoir reached a full supply level of $490.00 \mathrm{~m}$ a.s.l. (Roseires dam Resident Engineer, Personal Communication, 2017). The full supply level before the heightening of the dam never exceeded $481.00 \mathrm{~m}$ a.s.l. No explanation can be given for the paucity of algae in the reservoirs and at Khartoum during November-December 2017 except perhaps the relatively high content of suspended silt, which prevented the development of phytoplankton.

\section{Conclusions}

In conclusion, the physical and chemical characteristics of the water of Sennar and Roseires reservoirs did not change during the past fifty years. No unwelcome 
enrichment, which might occur because of introduction of industrial contaminants or diffusion of agrochemicals into Sennar and Roseires reservoirs and into the course of the Blue Nile upstream the two dams, was detected. It is pleasing that the waters of Sennar and Roseires reservoirs are of excellent quality for drinking being well within allowable limits set by the Sudanese Standards and Metrology Organization (SSMO 2008). The concentrations of heavy metals are within permissible limits set by WHO for drinking water (WHO 2011).

Fortunately, there was no regular build-up of heavy metal concentrations in the Blue Nile since pollutants entering the river, if any, are washed away with the annual flood. Environmentalists are alarmed that Nile pollution may become a problem after the completion of the Grand Ethiopian Renaissance Dam (GERD) when only a fraction of the Blue Nile water may reach Sudan allowing for the accumulation and regular build-up of pollutants. A similar problem of Nile pollution was reported in Egypt after the completion of Aswan High Dam when only $10 \%$ of River Nile water flows downstream Aswan High Dam failing to annually flush pollutants out of the Nile system within Egypt into the Mediterranean.

During the present study the impact of the heightening of Roseires Dam on the development of phytoplankton in the Blue Nile was detected. Visual observations as well as water samples collected from the two reservoirs and from the Blue Nile at Khartoum showed that recurrent peaks reported by previous workers did not appear in the Blue Nile while turbidity and concentrations of nutrients remained unexpectedly high with no signs of any algal bloom during 2016 - 2017. No explanation can be given for the scarcity of algae in the large masses of water stored in Roseires reservoir (full supply level of $490.00 \mathrm{~m}$ a.s.l.) during 2017 except perhaps for the effect of the high silt content which remained suspended for a longer time than usual after the flood subsided.

\section{Acknowledgments}

We gratefully acknowledge the funding of this work by the Ministry of higher Education and Scientific Research, Sudan. The authors would like to express appreciation for the support of the Sudanese Electricity Distribution Company Ltd. and Dams Implementation Unit for provision of accommodation in Damazin and Sennar during our field visits. Our thanks go to the top engineers of both Roseires and Sennar dams for providing a tugboat and a power-motorized fishing boat.

\section{References}

Allen SE (1989) Chemical Analysis of Ecological Materials. Second Edition. Oxford: Blackwell Scientific Publications.

Brook AJ (1954) A Systematic Account of the Phytoplankton of the Blue and White Nile. Annals and Magazine of Natural History 12(VII): 648-656. 
Cleve-Euler A (1951) Die Diatomeen von Schweden und Finland. [The Diatoms of Sweden and Finland.] Bibliotheca Phycologica Band 5. New York: 3301 Lehre Verlag von J Cramer.

Desikachary TV (1959) Cyanophyta. New Delhi: ICAR Monographs.

Hammerton D (1970a) Water Characteristics and Phytoplankton Production. Eleventh Annual Report. University of Khartoum: Hydrobiological Research Unit, 1963-1964, $5-12$.

Hammerton D (1970b) Longitudinal Survey of the Blue Nile. Twelfth Annual Report. University of Khartoum: Hydrobiological Research Unit, 1964-1965, 5-8.

Hammerton D (1971a) Blue Nile Survey. Studies of Primary Production in the River Nile. Thirteenth Annual Report. University of Khartoum: Hydrobiological Research Unit, 1965-1966, 16-17.

Hammerton D (1971b) Blue Nile Survey. Fourteenth Annual Report. University of Khartoum: Hydrobiological Research Unit, 1966-1967, 3-9.

Hammerton D (1971c) Blue Nile Survey. Fifteenth Annual Report. University of Khartoum: Hydrobiological Research Unit, 1967-1968, 5-14.

Hammerton D (1971d) Blue Nile Survey. Sixteenth Annual Report. University of Khartoum: Hydrobiological Research Unit, 1968-1969, 5-9.

Hammerton D (1972a) Blue Nile Survey. Seventeenth Annual Report. University of Khartoum: Hydrobiological Research Unit, 1969-1970, 6-10.

Hammerton D (1972b) The Nile River: A Case History. In River Ecology and Man. Edited by RT Oglesby, CA Carlson, JA McCann. New York and London: Academic Press.

Krammer K (1991a) Morphology and Taxonomy in Some Taxa of the Genus Aulacoseira Thwaites (Bacillariophyceae) I. Aulacoseira distans and Similar Taxa. Nova Hedwigia 52(1-2): 89-112.

Krammer K (1991b) Morphology and Taxonomy in Some Taxa of the Genus Aulacoseira Thwaites (Bacillariophyceae) II. Taxa in the A. Granulata, Italica- and LirataGroups. Nova Hedwigia 53(3-4): 477-496.

Lund JWG, Le Cren ED, Kipling C (1958) The Inverted Microscope Method of Estimating Algal Numbers and the Statistical Basis of Estimation by Counting. Hydrobiologia 11(2): 143-170.

Mackereth FJ, Heron J, Talling JF (1978) Water Analysis: Some Revised Methods for Limnologists. Freshwater Biological Association Scientific Publication No. 36.

Omer AYA, Ali YSA, Roelvink JA, Dastgheib A, Paron P, Crosato A (2015) Modelling of Sedimentation Processes inside Roseires Reservoir (Sudan). Earth Surface Dynamics 3(Apr): 223-238.

Prescott GW (1962) Algae of the Western Great Lakes Area. Dubuque, Iowa: Wm C. Brown Co. Inc.

Rźoska J, Brook AJ, Prowse GA (1955) Seasonal Plankton Development in the White and Blue Nile near Khartoum. Verhandlungen der Internationalen Vereinigung fur Theoretische und Angewandte Limnologie 12(1): 327-334.

Sheath RG, Wehr JD (2015) Introduction to the Freshwater Algae. In Freshwater Algae of North America. Edited by JD Wehr, RG Sheath, JP Kociolek. San Diego: Academic Press, 2015, 1-11.

Sinada F (1972) Ecological and Productivity Studies on the Phytoplankton of the Blue and White Nile at Khartoum. M.Sc. Thesis. Khartoum: Faculty of Science, University of Khartoum.

Sinada F, Abdel Karim AG (1984a) Physical and Chemical Characteristics of the Blue Nile and the White Nile at Khartoum. Hydrobiologia 110(1): 21-32. 
Sinada F, Abdel Karim AG (1984b) A Quantitative Study of the Phytoplankton in the Blue and White Nile at Khartoum. Hydrobiologia 110(1): 47-55.

Sinada F, Yousif S (2012) An Updated Checklist of the Phytoplankton of the Blue Nile at Khartoum. Sudan Journal of Science 5(1). http://sciencejournal.uofk.edu.

Sinada F, Yousif S (2013) Water Chemistry and Quality of the Blue Nile at Khartoum. Sudan Journal of Science 5(2): 31-43.

SSMO - Sudanese Standards and Metrology Organization (2008) Drinking Water Guidelines Bulletin. Sudan.

Strickland JDH, Parsons TR (1977) A Practical Handbook of Seawater Analysis 167. Second Edition. Ottawa: Queen's Printer. Fisheries Research Board of Canada Bulletin.

Talling JF, Rźoska J (1967) The Development of Plankton in relation to Hydrological Regime in the Blue Nile. Journal of Ecology 55(3): 637-662.

WHO (2011) Guidelines for Drinking - Water Quality. Fourth Edition. Geneva Switzerland: World Health Organization.

Yousif S (2004) Observations on the Phytoplankton and Water Quality of the Blue Nile at Khartoum. M.Sc. Unpublished Thesis. Khartoum: University of Khartoum. 
